\title{
Effects of Change Orders through Technical Programs on Construction Projects in Jordan
}

\author{
Ahmed Ali Khatatbeh \\ Department of Civil Engineering, Faculty of Engineering, Al-Albayt University, Mafraq 25113, Jordan
}

\begin{abstract}
Regarding construction projects, no project is implemented exactly as planned. Changes in construction projects are common due to the dynamic nature of the construction process. It is necessary to use effective and appropriate tools by project management to support decision-making and control changes during all stages of project implementation. This study examined the effects of change orders through technical programs on construction projects in Jordan and focused on how to overcome these effects by making usual orders that can be handled by each of the contracting parties. Also, this study added an advantage by not addressing the negative effects of change orders, but it provided many positive effects of change orders by using technical programs method, which has not been yet researched in Jordanian studies in particular, and in global studies in general. The researcher used descriptive analytical method by interviews to collect data through nine questions to a random sample of 30 engineers selected form constructions projects in Jordan. The results related to the study questions on the effect of change orders through technical programs on construction projects in Jordan showed that, most of the study samples confirm that change orders through technical programs decrease the cost of the projects, cause no need for more materials, cause no delay in the completion schedule, enhances the quality of work, and increase the productivity of the work force. The study recommended applying integrated change management system with technical supports form different technologies, developing effective innovative and practical solution to manage change orders and increase training programs to qualify and increase engineering skills in dealing with ICT (information and communication technologies) program.
\end{abstract}

Key words: Change orders, construction projects, technical programs, ICT (information and communication technologies).

\section{Introduction}

The construction sector is one of the largest industrial sectors in the world in general. Therefore, the process of implementation of the projects had to use developed management systems to support decision-making in line with the reality of the economic criteria case and the fields of global production in order to be implemented within the specified time and within efficient budget. These mean serious attempt to use the effective and appropriate new tools in the management, planning time and cost since the approval of the project until its finish, to reach success of construction process without financial losses, non-wasting time and reduce the management changes that accompany the stages of the project completion.

The difficulty of the construction sector as a result of

Corresponding author: Ahmed Ali Khatatbeh, assistant professor, chairman of civil engineering department, research fields: civil engineering and project management. varying stakeholders' participation, creates it to be different from other sectors. This difficulty provides increase mostly to not needed situation like differences with their attached consequences, and the additional change orders on a project, the better the probability that they become time intense and costly in construction projects [1].

The study of Yadeta [2] confirmed that change orders is an essential feature of the construction project features, and it is rare that the implementation of any project, goes according to its plans without any change, change orders associated with the projects and inherent to it, which creates challenges for the parties of the project.

In order to overcome this information management and communication lack, more importance is given to ICT (information and communication technologies) instruments.

Both designers and software/hardware developers 
have employed numerous ICT tools for giving solutions to the construction sector and facilitated the implementation of change orders [3].

Change orders through technical programs are accountable to most cases of capability to complete and hand over project works as originally agreed upon at the beginning of the work without the increase in the project cost and an extended duration of completion, which consider the two main effects observed for original change orders without applying technical programs [4].

\subsection{Statement of the Problem}

Many studies have confirmed that the most important reasons for the delay of the completion of the construction projects are change orders that effect on reducing productivity and the increase in the cost and time that it appear repeatedly especially through the implementation of construction project, which causes the re-design of the project, or even re-start on it. Therefore, the current study considers the first of its kind to avoid these negative effects and apply technical programs with change orders. This study will try to solve negative effects and shed light on some of effects of change orders through technical programs on construction projects in Jordan.

\subsection{Questions of the Study}

The main question is: Are there effects of change orders through technical programs on construction projects in Jordan?

And the sub-questions are:

(1) Are there effects of change orders through technical programs on cost of construction projects in Jordan?

(2) Are there effects of change orders through technical programs on time of construction projects in extended duration of completion in Jordan?

(3) Are there effects of change orders through technical programs on quality of construction projects in Jordan?

\subsection{Importance of the Study}

The importance of this study emerges in examining effects of change orders through technical programs on construction projects in Jordan and this study focuses on how to overcome change orders that occur during the construction of projects and make usual orders that can be handled by each of the contracting parties. In addition, this topic of change orders through technical programs has not been addressed in Jordanian studies yet in particular, and in global studies in general; on the other hand, the research takes additional advantage that it is not addressing the negative effects of change orders but it is setting a many positive effects of change orders by using technical programs method.

\subsection{Purpose of the Study}

The purpose of this study is to analyze the effects of change orders through technical programs on construction projects in Jordan.

Also the study aimed at:

- analyze the effects of change orders through technical programs on cost of construction projects in Jordan;

- analyze the effects of change orders through Technical programs on time of Construction Projects in extended duration of completion in Jordan;

- analyze the effects of change orders through technical programs on quality of Construction Projects in Jordan.

\section{Previous Studies}

\subsection{Study of Yadeta}

The objectives of the study [2] were firstly to determine the causes of variation orders; secondly to identify the impacts of variation orders; and lastly to recommend strategies to minimize variation orders. Through a comprehensive study of literature review, resulted in identification of 38 common causes of variation orders, 15 impacts of variation orders and 15 recommended strategies to minimize variation orders 
and these variables were mapped infrequency table. A desk study, interview and questionnaire survey were carried out to identify the causes of variation orders, their impacts on public building projects and to seek recommendations to reduce them. The desk study conducted on five selected projects and the causes of variation orders and their impacts on the projects were identified. Interviews were made with selected experienced public building project participants for expert opinion. The questionnaire responses were analyzed using the relative index method. A triangulation method on the desk study, survey and the literatures was done to improve the validity of the findings from the study. The results indicated that design changes, incomplete contract documents, and impediment in prompt decision making process were the most causes of variation orders. The results also showed that completion schedule delay, increase in project cost, and additional payments for contractor were the most impact of variation orders. The findings also suggested a number of recommended strategies to minimize variation orders.

\subsection{Study of Alaryan et al.}

This study [5] investigates the change orders in public and private construction projects in Kuwait. The study in this research presents the results of a questionnaire surveying the owners, contractors and consultants on a sample comprising 385 engineers representing the construction industry. The responses to the questionnaire helped in identifying the general characteristics of the construction industry in Kuwait as well as ranking the most common causes of changes, their effects on the projects and the control measures to address the changes. The results of the questionnaire indicate that the owner is the most responsible party causing changes. The study identifies that the first cause is change of plans by owner, otherwise increase in cost of the project is the first effect. All changes to design documents are checked and reviewed in the first control stage.

\subsection{Study of Ngwepe et al.}

This study [6] investigates the critical determinants of variation orders in public sector projects in South Africa. The paper assesses how variation orders occur in SA (South Africa) public sector construction projects and it focuses mainly on the causes as the professional team involved in a construction project. To achieve the objectives of the study, a critical review of literature was done coupled with a questionnaire survey to collect information on potential causes of variations in the public projects in South Africa. Through the review of literature, 48 causes of variation orders were identified which provided the basis for the formulation of the questionnaire. The questionnaire was distributed to professionals who work for companies that undertake public construction projects in South Africa. Targeted number of respondents was 50 ; however, a total of 70 questionnaires were sent out. Overall, 50 questionnaires were returned and, after a careful examination of the received questionnaires, only 39 were usable. These formed the basis of the analysis for the study, since it accounts for $78 \%$ of the initial sample. Findings revealed that the client is the major causes of variation orders in SA public sector construction projects. Client is closely followed by consultant, and then the third ranked is "differing site conditions". Causes of variation orders were further broken down into four categories namely; client related variation orders, consultant-related variation orders, contractor-related variation orders, and other-related variation orders.

\subsection{Study of El Karriri}

This study [7] aims to investigate the causes of variation orders in UNRWA (United Nations Relief and Works Agency) construction projects and to introduce how UNRWA contract conditions manage the observance of these variation orders. Three research methodologies were used to achieve these objectives by reviewing the researches that discussed the causes of variation orders and approaches to 
manage them, introducing how UNRWA contract clauses manage variation orders in construction projects and analyzing three cases (case studies) showing the causes of variation orders and how they were managed. The results showed that the majority of the recorded variation orders in UNRWA construction projects were related to client's (UNRWA) amendments, design changes, non availability of certain types of construction materials due to the difficulties in Gaza Strip and to the weather conditions which form one of the reasons for variation orders in UNRWA projects specially in the infrastructure works.

\subsection{Study of Sunday}

The study [1] examines the impact of variation on construction projects in relation to the handler that is the in-house staff and the consultants. To achieve the study objectives, a critical review of relevant literature was done coupled with questionnaire survey to collect information on potential causes of variations in the public projects with special emphasis on projects carried out by the Class 1 and 2 contractors for government. Through the literature review, 53 causes of variation orders were identified which provided the basis for the formulation of the questionnaire. The identified causes were earlier subjected to test by the professionals to determine the relevance of the causes of variation in Seychelles construction projects. 58 questionnaires were distributed to the in-house construction professionals, consultants and contractors involve in handling government projects. 30 in-house staff responded to the questionnaire and 18 responded by both the consultants and contractors who were involved in government construction projects. Through the analysis of the data, it was discovered that the projects handled by the consultants are more prone to variation orders than projects handled by the in-house professionals. Aside of the study also discovered that the percentage difference in the initial contract sums and final sums was significant both for the projects managed by the in-house project staff and the consultants but higher in the consultants managed projects. The study concluded that the projects handled by the consultants suffered both cost and time overruns than the projects handled by the in-house staff.

\section{Methodology}

\subsection{Introduction}

This part of the study discusses the research design, measurement procedure, and sampling design, which will be used as the methodology for this research.

\subsection{Study Methodology}

Researcher used descriptive analytical method which is based on the data collection.

\subsection{Participants}

The study population will include all engineers of construction project in Jordan. A random sample of 30 engineers will be selected from construction projects in Jordan.

\subsection{Instrument of the Study}

To identify the effects of change orders through technical programs on construction projects in Jordan in this study, the researcher used the interviews to collect data. The interview includes 9 questions which are:

(1) Do change orders through technical programs have effect on the cost of the projects? Increase or decrease?

(2) Do change orders through technical programs cause delay in completion schedule and delay in payment?

(3) Do change orders through technical programs cause demolition and re-work in the project?

(4) Do change orders through technical programs have effect on duration of individual activities? Increase or decrease?

(5) Do change orders through technical programs have effect on the productivity of workers? Increase or 
decrease?

(6) How do change orders through technical programs effect on the overhead expenses?

(7) How do change orders through technical programs effect on quality of work?

(8) Do change orders through technical programs cause the need for more materials and tools?

(9) Do change orders through technical programs cause additional money for contractor?

\section{Analysis of Results}

In this section, the answers of study questions by the study sample during the interview are presented.

For answering the main question which is: Are there effects of change orders through technical programs on construction projects in Jordan?

The researcher asked 30 engineers about the effects of change orders through technical programs on construction projects in Jordan and they answered 9 questions which were divided into three Sub- questions of study:

For answering the first sub-questions which is: Are there Effects of Change Orders through Technical programs on cost of Construction Projects in Jordan?

Are change orders through technical programs effect on the cost of the projects? Increase or decrease?

The results showed that most of study samples confirm that there is effect of change orders through technical programs on the cost of the projects and this effect is a positive effect, which means that change orders through technical programs decrease the cost of the projects.

How change orders through technical programs effect on the overhead expenses?

The results showed that the most of study sample confirm that there is effect of change orders through technical programs on the overhead expenses and this effect is a positive effect, which means that change orders through technical programs do not increase the cost of the projects.

Do change orders through technical programs cause need of more materials and tools?

The results showed that the most of study sample confirm that the change orders through technical programs cause no need of more materials.

Do change orders through technical programs cause additional money for contractor?

The results showed that most of study samples confirm that the change orders through technical programs cause additional money for contractor.

For answering the second sub-question which is: Are there effects of change orders through technical programs on time of construction projects in extended duration of completion in Jordan?

Do change orders through technical programs cause delay in completion schedule and delay in payment?

The results showed that most of study samples confirm that change orders through technical programs cause no delay in completion schedule and delay in payment.

Do change orders through technical programs cause demolition and re-work in the project?

The results showed that most of study samples confirm that the change orders through technical programs cause no demolition and re-work in the project.

Do change orders through technical programs have effect on duration of individual activities? Increase or decrease?

The results showed that the most of study sample confirm that there are effects of change orders through technical programs on duration of individual activities and this effect is a positive effect, which means that change orders through technical programs do not increase the duration of individual activities.

For answering the third sub-questions which is: Are there effects of change orders through technical programs on quality of construction projects in Jordan?

How change orders through technical programs effect on quality of work?

The results showed that most of study samples confirm that there are effect of change orders through 
technical programs on the quality of work and this effect is a positive effect, which means change orders through technical programs enhance the quality of work.

Do change orders through technical programs have effect on the productivity of workers? Increase or decrease?

The results showed that most of study samples confirm that there are effect of change orders through technical programs on the productivity of workers and this effect is a positive effect, which means that change orders through technical programs increase the productivity of workers.

\section{Discussion and Recommendations}

\subsection{Discussing the Results Related to the Questions}

The first question is: Are there effects of change orders through technical programs on the cost of construction projects in Jordan?

The results of the study showed that there are effects of change orders through technical programs on cost of construction projects in Jordan. The researcher explains these results that technical programs are able to find the cost of possible change orders of the contractor's value through front end estimating or review of the contractor's proposal by engaging an outside cost consultant or through internal estimators. Also, changes by technical programs may be for dimensional clarifications or just added notes for more information and without need of more materials and tools.

The second question is: Are there effects of change orders through technical programs on the time of construction projects in extended duration of completion in Jordan?

The results of the study showed that there are effects of change orders through technical programs on the time of construction projects in extended duration of completion in Jordan. The researcher explains these results that change orders through technical programs make sure that the contractors present the change proposal in a timely and complete manner. And it facilitate to owner that he must also realize that timely appraisal of change order suggestions is significant to the project and particularly to the contractors, who must complete the project.

The third question is: Are there effects of change orders through technical programs on quality of construction projects in Jordan?

The results of the study showed that there are effects of change orders through technical programs on quality of construction projects in Jordan. The researcher explains these results that the change orders have significant effects on the construction projects. They enhance the quality of work, and increase workmanship. Change orders through technical programs increase the work productivity. Change orders through technical programs are easy to manage at the initial phases of construction, which decreases the rework and provide additional results for the stage. Change orders through technical programs reduce arguments between owners and contractors and the owner has to disburse additional money for extra work.

\subsection{Recommendations}

Designing successful technical programs of change orders is very challenging, and one can difficultly discover a software instrument, that works with this subject. The researcher recommends the followings:

- apply integrated change management system with technical supports from different technologies;

- develop effective, innovative and practical solutions to manage the change orders;

- increase the training programs in order to qualify and increase the engineering skills in dealing with ITC program;

- conduct further research by performing similar studies dealing with the effects of design form through technical programs on construction projects in Jordan;

- conduct further research regarding the relationship between technical programs on construction projects. 


\section{References}

[1] Sunday, O. 2010. "Impact of Variation Orders on Public Construction Projects.” In Proceedings of 26th Annual ARCOM Conference, 101-10.

[2] Yadeta, A. 2014. "Assessing the Impact of Variation Orders on Public Building Projects in Addis Ababa." Academia.

[3] Hao, Q., Shen, W., Neelamkavil, J., and Thomas, Russ. 2008. "Change Management in Construction Projects.” Presented at the International Conference on Information Technology in Construction Santiago, Chile.

[4] Charoenngam, C., Coquinco, S. T., and Hadikusumo, B. H. W. 2003. "Web-Based Application for Managing
Change Orders in Construction Projects.” Construction Innovation 3: 197-215.

[5] Alia, A., Emadel, B., and Ashraf, E. 2014. "Causes and Effects of Change Orders on Construction Projects in Kuwait." Journal of Engineering Research and Applications 4 (7): 1-8.

[6] Lusca, N., Clinton, A., and Wellington, T. 2014. “The Critical Determinants of Variation Orders on SA Public Sector Construction Projects.” Journal of Construction Engineering and Management 137 (90): 663-7.

[7] El Karriri, A. 2012. Investigating Variation Orders Observance in UNRWA Construction Contracts: Case Study. Presented at the 4th International Engineering Conference-Towards Engineering of 21st Century. 